\title{
Amantadine resistance of clade 2.3.2 H5N1 Avian Influenza Virus from Waterfowl in Indonesia
}

\author{
Hewajuli DA ${ }^{1}$, Dharmayanti NLP ${ }^{1}$, Wibawan IWT $^{2}$ \\ ${ }^{I}$ Department of Virology, Indonesian Centre Research Institute for Veterinary Science, \\ Jl. R.E. Martadinata No 30 Bogor, 16124 - Indonesia \\ ${ }^{2}$ Department of Medical Microbiology, Faculty of Veterinary Medicine, \\ IPB University, Jl. Agatis, Dramaga Campus, Bogor 16680 - Indonesia \\ E-mail:dhewajuli@yahoo.com \\ (received 23-06-2021; revised 17-09-2021; accepted 27-09-2021)
}

\begin{abstract}
ABSTRAK
Hewajuli DA, Dharmayanti NLP, Wibawan IWT. 2021. Resistensi amantadin terhadap virus avian influenza subtipe H5N1 clade 2.3.2 di Indonesia. JITV 26(3):115-123. DOI: http://dx.doi.org/10.14334/jitv.v26i3.2764.

Tujuan penelitian ini adalah mengetahui sensitifitas virus avian influenza subtipe H5N1 clade 2.3 .2 asal Indonesia terhadap antiviral amantadin melalui uji molekuler dan in vitro. Penelitian dilakukan dengan isolasi dan identifikasi virus, analisis nukleotida, uji sensitifitas amantadin di sel MDCK. Hasil penelitian menunjukkan bahwa titer EID $_{50}$ isolat clade 2.3.2 subtipe $\mathrm{H} 5 \mathrm{~N} 1$ adalah rata rata $>10^{8} \mathrm{EID}_{50} / \mathrm{ml}$. Analisis pohon filogenetik gen $\mathrm{M} 2$ dari keenam virus avian influenza subtipe H5N1 clade 2.3.2 asal Indonesia mempunyai kedekatan dengan virus avian influenza subtipe H5N1 clade 2.3.2 asal Vietnam, Cina, Hongkong. Substitusi protein M2 (V27I) diidentifikasi pada enam isolat subtipe H5N1 clade 2.3.2 asal Indonesia. Avian influenza subtipe H5N1 clade 2.3.2 dapat menyebabkan pembentukan CPE dan uji HA bereaksi positif pada sel MDCK dengan konsentrasi amantadine hydrochloride yang tidak toksik. Hasil analisis genetik gen M2 terhadap resistensi amantadin berkorelasi dengan hasil uji HA dan pembentukan CPE pada sel MDCK sehingga dapat disimpulkan bahwa resistensi amantadin telah diidentifikasi pada virus avian influenza subtipe H5N1 clade 2.3.2 yang diisolasi dari Indonesia
\end{abstract}

Kata Kunci : Avian influenza subtipe H5N1 clade 2.3.2, Unggas air, Resistensi amantadin, Indonesia

\begin{abstract}
Hewajuli DA, Dharmayanti NLP, Wibawan IWT. 2021. Amantadine resistance of clade 2.3.2 H5N1 Avian Influenza virus from waterfowl in Indonesia. JITV 26(3): 115-123. DOI: http://dx.doi.org/10.14334/jitv.v26i3.2764.

The objective of this research was to know the sensitivity of H5N1 clade 2.3.2 AIV from Indonesia to antiviral drug (amantadine) through molecular and in vitro tests. The study was conducted by virus isolation and identification, nucleotide analysis, and susceptibility to the amantadine hydrocloride in MDCK cells. The study result represented that the mean EID $_{50}$ isolates of H5N1 clade 2.3.2 AIV was determined of $>10^{8} \mathrm{EID}_{50} / \mathrm{ml}$. The analysis of phylogenetic tree of M2 gene from six viruses of H5N1 clade 2.3.2 AIV from Indonesia were closed with H5N1 clade 2.3.2 AIV avian influenza viruses from Vietnam, China, Hongkong. The substitution of M2 protein (V27I) was identified in six isolates H5N1 clade 2.3.2 AIV isolated from Indonesia. Avian influenza of clade 2.3.2 H5N1 subtype from Indonesia produced the formation of CPE and the positive HA reaction with non-toxic concentration of amantadine hydrochloride in MDCK cells. The result of genetic analysis of M2 gene for amantadine resistance was related with the results of HA test and the formation of CPE in MDCK cells. These results established that amantadine resistance have been identified in H5N1 clade 2.3.2 AIV viruses isolated from Indonesia
\end{abstract}

Key Words: Avian Influenza of clade 2.3.2, Waterfowl, Amantadine resistance, Indonesia

\section{INTRODUCTION}

Highly pathogenic avian influenza (HPAI) virus has been causing significant outbreaks in poultry in Indonesia since 2003 (Wibawa et al. 2014; Dharmayanti et al. 2014). The avian influenza viruses were grouped into $11 \mathrm{H} 5$ clades actively circulating up to 2012 (WHO/OIE/FAO H5N1 Evolution Working Group 2014). The 2.1 clade of H5N1 viruses were the primary clades of $\mathrm{H} 5 \mathrm{~N} 1$ viruses circulated in Indonesia throughout among 2003 - 2011 (Dharmayanti et al.
2013). The high mortality of ducks caused influenza $A$ (H5N1) viruses of clade 2.3.2.1 were reported in Java Island, Indonesia, at September 2012 (Dharmayanti et al. 2014). To date, transmission of clade $2.1 \mathrm{H} 5 \mathrm{~N} 1$ subtype to humans have been discovered in Indonesia while infection of clade 2.3.2 H5N1 subtype in humans have not been officially reported in Indonesia.

The human case of H5N1 clade 2.3.2 AIV was identified in Bangladesh and Canada (East 2018; Smith \& Donish 2015). In Indonesia, the H5N1 clade 2.3.2 AIV have been not detected in human. However, this is 
possible that the $\mathrm{H} 5 \mathrm{~N} 1$ clade 2.3 .2 can be transmitted to human in Indonesia. Therefore, the anticipation of clade 2.3.2 transmission to human is necessary. The prophylactic control can use the effective antiviral drugs. The antiviral drugs for the prophylactic control and therapeutics of influenza infection in humans is distinguished into two classes involve the M2 inhibitors (amantadine and rimantadine) and the neuraminidase inhibitors (oseltamivir and zanamivir) (Ison 2013).

The effectiveness of antiviral drugs will depend on the susceptibility $\mathrm{H} 5 \mathrm{~N} 1$ avian influenza viruses. The substitutions of M2 protein at residues $26,27,30,31$, and 34 are the markers of amantadine resistance. The most of H5N1 clade 2.1 AIV were resistant to amantadine in Indonesia (Cheung et al. 2006; Dharmayanti et al. 2010).

The amantadine resistance studies for $\mathrm{H} 5 \mathrm{~N} 1$ clade 2.1 AIV have been done in Indonesia but the amantadine resistance research for $\mathrm{H} 5 \mathrm{~N} 1$ clade 2.3.2 AIV have no more in Indonesia. Previous study described substitution at residu 27 (V27I) M2 protein of H5N1 clade 2.3.2 AIV in Indonesia. However, the M2 phenotypic analysis of $\mathrm{H} 5 \mathrm{~N} 1$ clade 2.3.2 AIV have not yet been performed in Indonesia. The monitoring of H5N1 subtype of 2.3.2 clade isolated from poultry for antiviral resistance is important to control of the disease. The purpose of this research is to study the amantadine susceptibility among avian influenza of 2.3.2 clade isolated from Indonesia based on identification of genetic markers of amantadine resistance and phenotypic analysis in MDCK cells.

\section{MATERIALS AND METHODS}

\section{Virus isolation and identification}

Samples were sick or inanimate birds that obtained from poultry and live bird markets. In outbreak of avian influenza, samples were collected from inanimate birds. Tissue samples were collected from the cloaca swab, trachea swab, bronchus, brain, intestine, spleen, and lung, and transported to laboratory. The tissue sample was cultivated in three to five embryonated eggs specific pathogen free embryonated chicken eggs of 9 11 days incubation. The eggs are incubated at $37^{\circ} \mathrm{C}$ (range $35-39^{\circ} \mathrm{C}$ ) for $2-7$ days. Viruses were propagated according to the World Organization for Animal Health manual (OIE 2021). The harvested allantoic fluids from specific pathogen free embryonated chicken eggs were stored at $-80^{\circ} \mathrm{C}$ for futher examination. The hemagglutination agglutination (HA) is used as a sceering test that indicates a high probability of the presence of influenza A viruses. The presence of $\mathrm{H} 5 \mathrm{~N} 1$ subtype avian influenza were confirmed by Reverse Transcriptation Polymerase Chain Reaction (RT-PCR) methods with the HA primer sequences of RT PCR method referred to the primers design of Dharmayanti et al. 2016 and Lee et al. 2001; the NA primer sequence (Wright et al. 1995), the Matrix primer sequence (Hoffmann et al. 2001). The method of Reed \& Muench was used to calculate the virus titer (EID50, $\log 10 / \mathrm{ml}$ ) in 10 day old embryonated chicken eggs incubated at temperature of $35^{\circ} \mathrm{C}$ for 40 hour (Reed \& Muench 1938).

Six avian influenza virus of 2.3 .2 clade strains, designated A/duck/Indonesia/Brs17/2013 (H5N1), A /duck/ Indonesia/Brs 34/2013 (H5N1), A /duck/Indonesia/Brs 62 /2013 (H5N1), A /Muscovy duck /Indonesia/Serang /Srg 17/2016 (H5N1), and A/Duck/Indonesia/Lamongan/Lmn Tr/2016 (H5N1) were isolated from H5N1 outbreaks in Waterfowl in East Java, West Java Provinces and surveillance program in Banten Provinces of Indonesia. Isolates used as representative viruses in this study were selected based on location from outbreaks in the country and species. Furthermore, representative clade 2.3.2 viruses of each year were determined by the amantadine sensitivity of viruses with MDCK cellbased virus reduction assay and genetic analysis of amantadine resistance markers of the M2 protein.

\section{Susceptibility to the adamantanes}

The examination of amantadine toxicity had been done before the biological antiviral assay was tested. The examination of amantadine toxicity was intended to determine the non toxic concentration of amantadine hydrochloride $(\mu \mathrm{g} / \mathrm{ml})$ for MDCK cells. The amantadine hydrochloride concentrations tested were 2 $\mu \mathrm{g} / \mathrm{ml}, \quad 4 \mu \mathrm{g} / \mathrm{ml}, \quad 5 \mu \mathrm{g} / \mathrm{ml}$ and $7 \mu \mathrm{g} / \mathrm{ml}$. Each concentration was replicated 3 times, subsequently observed with a microscope through 3-4 days post infection (Dharmayanti et al. 2010; Cheung et al. 2006).

The amantadine sensitivity of viruses was analyzed in MDCK cell. The phenotypic assay of antiviral activity for each virus were conducted in confluent monolayer of MDCK cells in 96 well plate in triplicate by haemagglutination (HA) reduction assay and described by Cytophatic Effect (CPE) (Cheung et al. 2006; Dharmayanti et al. 2010). Monolayers of MDCK cells treated with amantadine hydrochloride at $2 \mu \mathrm{g} / \mathrm{ml}$ and $4 \mu \mathrm{g} / \mathrm{ml}$ concentrations (obtained from stock solution of $5 \mathrm{mg} / \mathrm{ml}$ in Phosphate Buffered Saline (PBS) were infected with $10^{6-8}$ EID $_{50}$ virus then cultured for $48 \mathrm{~h}$ at $37^{\circ} \mathrm{C}$ with $5 \% \mathrm{CO} 2$. Supernatants of MDCK cell culture were harvested for HA reduction assay. Replication of virus in MDCK cell culture was measured by HA titers of individual well supernatants. 
Table 1. Primer sequences of gene (HA, NA, Matrix) that used for RT-PCR assay (Dharmayanti et al. 2016 ; Lee et al. 2001; Wright et al. 1995; Hoffmann et al. 2001)

\begin{tabular}{lc}
\hline \hline Primers & Primer sequences \\
\hline M52C & 5'- CTTCTAACCGAGGTCGAAACG-3' \\
M253 & 5'- AGGGCATTTTGGACAAAG/TCGTCTA-3' \\
H5-F & 5'-ACACATGCYCARGACATACT-3' \\
H5-R & 5'- CTYTGRTTYAGTGTTGATGT-3' \\
H5-NLP86F & 5'-CAGAGCAGGTTGACACAATC-3' \\
H5-NLP463R & 5'-CCAGGTATGGACATGCTGAG-3' \\
H5-ID252F & 5'-CGAATTCACCAATGTGCCAG-3' \\
H5-ID889R & 5'-GAGTCTGACACCTGGTGTTG-3' \\
N1-1 & 5'-TTG CTT GGT CGG CAA GTGC-3' \\
N1-2 & 5'-CCA GTC CAC CCA TTT GGA TCC-3' \\
\hline
\end{tabular}

\section{Nucleotide analysis}

The sequencing analysis of M2 gene used the Matrik primer referred to the primers design of Hoffman et al. 2001. The genetic of transmembrane region of the M2 protein was analyzed, and residues (L26, V27, A30, S31, and G34) were the molecular markers of adamantine resistance. The RNeasy kit (QIAGEN) was used for RNA extraction, and RT-PCR was conducted using the SuperScript III One-Step RTPCR System with Platinum Taq DNA Polymerase (In vitrogen).The DNA sequence used the Sanger method with Bioedit versi 7 and the Clustal W program.. The phylogenetic trees were constructed using the MEGA 6 software with neighborjoining algorithm and the Kimura two-parameter model. Tree topology was evaluated by Bootstrap values of 1000 replicates.

\section{RESULTS AND DISCUSSION}

\section{Results}

\section{Virus isolation}

The avian influenza viruses of H5N1 subtype were obtained from the live bird markets and duck farms. Eight isolates of avian influenza H5N1 viruses were isolated from apparently healthy ducks and six isolates from dead ducks at 2016. Detection using RT PCR method indicated that these isolates were avian influenza $\mathrm{H} 5 \mathrm{~N} 1$ viruses. Their mean $\mathrm{EID}_{50}$ was determined as each of $>10^{8}$ EID50/ml. In another, the mean $\mathrm{EID}_{50}$ of influenza A subtype $\mathrm{H} 5 \mathrm{~N} 1$ viruses isolated at 2013 were $>10^{8}$ EID50/ml.

\section{Genetic analysis}

Phylogenetic tree analysis of the M2 gene of six H5N1 subtype of clade 2.3.2 from Indonesia were closed with H5N1 subtype of clade 2.3.2 from Vietnam, China, Hongkong (Figure 1.). Compared to the A/chicken/East Java/BL-IPA/2003 strain, the M2 gene in 6 representative strains from Indonesia contains amino acid substitutions at positions 27 (V27I). Even though the M2 V27I substitution have been reported in clade 2.3.2 viruses from Indonesia since 2012, the M2 V27I mutation had not been reported previously in clade 2.1.3 viruses from Indonesia.

The results of the M2 gene analysis are shown in Figure 2. The nucleotide sequence of M2 gene of clade 2.3.2 viruses from Indonesia isolated at 2013 and 2016 showed that these viruses are probably still susceptible to amantadine because the established markers of M2 channel inhibitor resistance of amino acid mutations in $26,27,30,31,34$ residues were not found in the M2 protein of these viruses. However, screening of amino acid mutations of the M2 protein in 26, 27, 30, 31, 34 residues are used to determine whether clade 2.3.2 viruses from Indonesia isolated at 2013 and 2016 have maintained its susceptibility to amantadine. Since these amino acid substitutions (V27I) characterized in the M2 protein of clade 2.3.2 viruses from Indonesia isolated at 2013 and 2016 were unusually genetic markers of resistant viruses, these viruses must be verified experimentally to confirm the resistance to amantadine.

\section{Biological antiviral assay}

Biological antiviral assay showed that Amantadine hydrochloride at a concentrations of $2 \mu \mathrm{g} / \mathrm{ml}$ and $4 \mu \mathrm{g}$ $/ \mathrm{ml}$ were not toxic for MDCK cells, whereas 


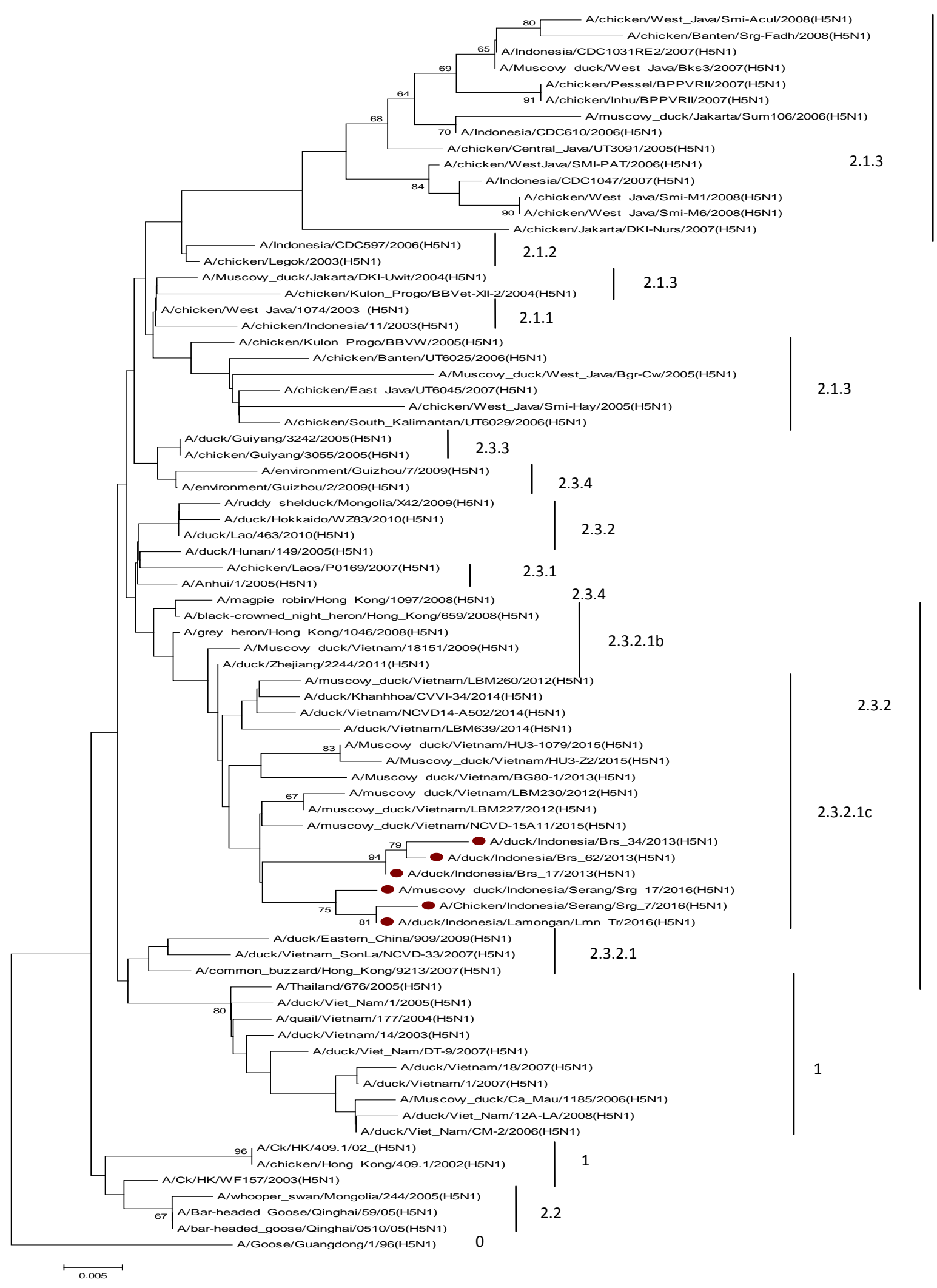

Figure 1. Phylogenetic tree of H5N1 clade 2.3.2 AIV M2 gene sequences. The phylogenetic tree was constructed in MEGA version 6 (www megasoftware.net) using neighbor -joining analysis with 1000 bootstrap replicates and the Kimura 2 parameter model. The H5N1 clade 2.3.2 AIV from waterfowl characterized in this study are indicated with red dot. The M2 tree was rooted are A/Goose/Guangdong/1/96(H5N1). 


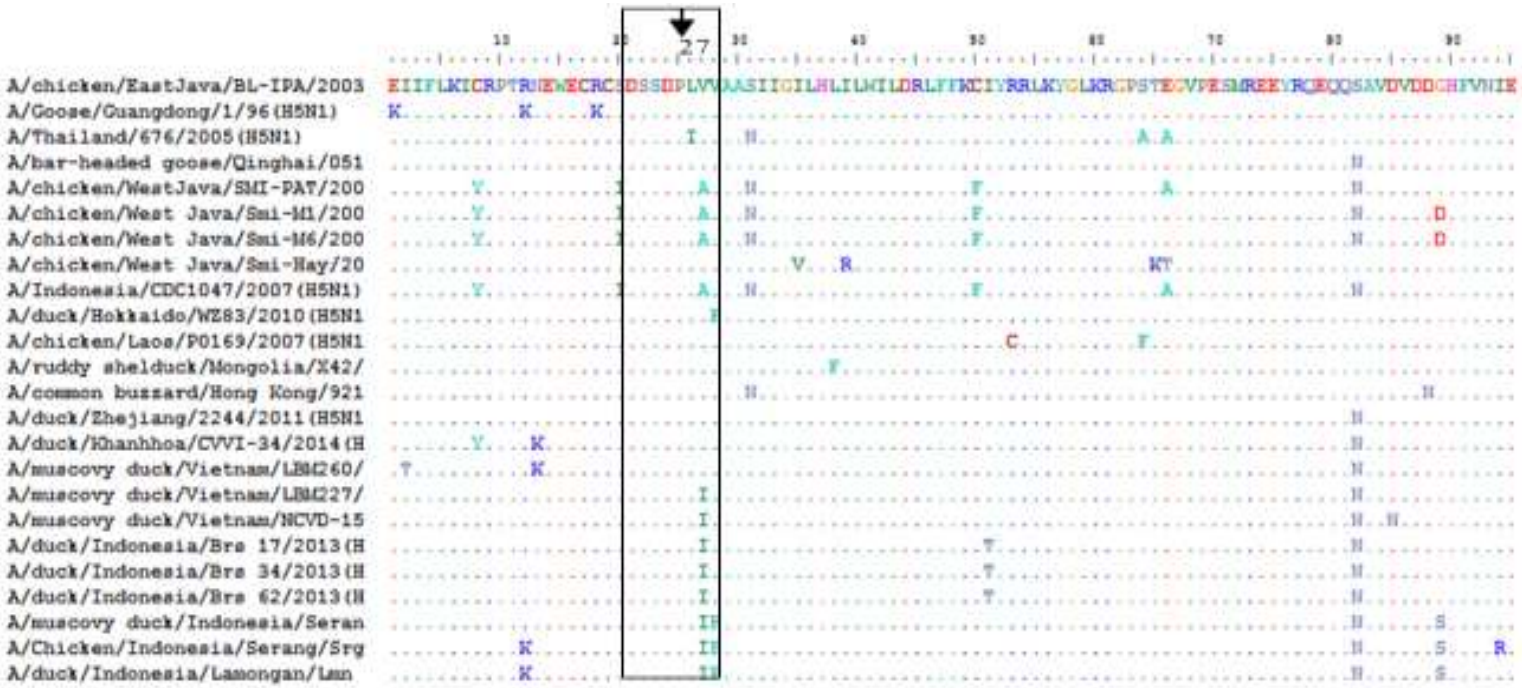

Figure 2. Multiple sequence alignment of M2 protein of avian influenza viruses of clade 2.3.2 H5N1 subtypes from waterfowl
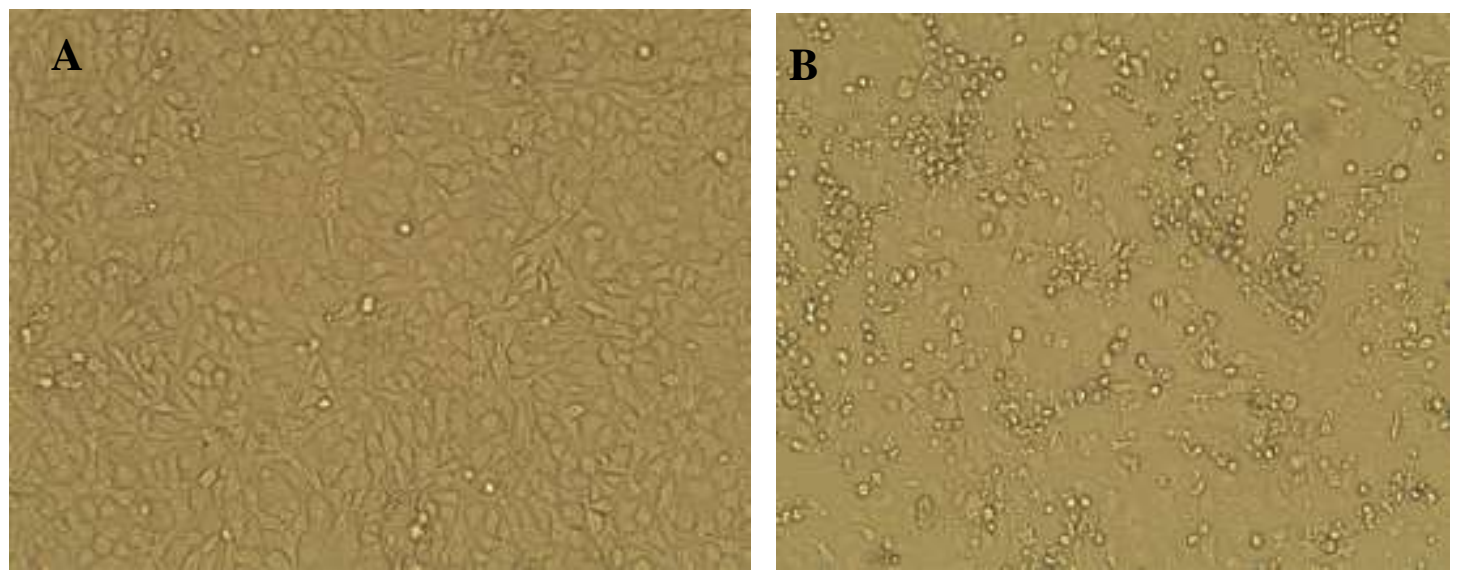

Figure 3. A) MDCK cell that shown non cytopathic effects (CPE). B) Resistence of avian influenza viruses of clade 2.3.2 subtype H5N1 caused CPE in MDCK cell treated with amantadine hydrocloride

amantadine hydrochloride at a concentrations of $5 \mu \mathrm{g} /$ $\mathrm{ml}$ and $7 \mu \mathrm{g} / \mathrm{ml}$ were toxic for MDCK cells. The HA titer of H5N1 subtype of clade 2.3.2 from Indonesia could be discovered on the amantadine-MDCK cells. The mean titers were 3 to $7 \log 2$. The HA titers and CPE - MDCK cells were influenced by the EID $_{50}$ titers and the period of isolation of clade 2.3.2 H5N1subtype viruses and amantadine hydrocloride concentration. The majority of viruses isolated at 2013 with $\leq 10^{7}$ EID $_{50}$ gave positive $\mathrm{HA}$ reaction $\left(\leq 2^{1}\right)$, but the virus with EID $_{50} 10^{7}$ gave positive HA reaction with varied titers $\left(\geq 2^{2}\right)$ and generated CPE in MDCK cells with diverse concentrations of amantadine hydrochloride. Nevertheless, all of viruses isolated at 2016 with EID $_{50} 10^{6}-10^{8}$ were resistance-amantadine hydrochloride in non toxic concentration $(2 \mu \mathrm{g} / \mathrm{ml}, 4$ $\mu \mathrm{g} / \mathrm{ml})$ since these gave positive HA reaction $\left(\geq 2^{2}\right)$ and formed CPE in MDCK cells (Figure 3).
Antiviral drugs of amantadine hydrocloride $(2 \mu \mathrm{g} /$ $\mathrm{ml}$ and $4 \mu \mathrm{g} / \mathrm{ml}$ concentrations) could not prevented infection of $\mathrm{H} 5 \mathrm{~N} 1$ subtype of clade 2.3.2 from Indonesia isolated at 2016 with EID $_{50} 10^{6}-10^{8}$ in MDCK cells. It is similar for H5N1 subtype of clade 2.3.2 from Indonesia isolated at 2013 with titer $\mathrm{EID}_{50} 10^{8}$ for these viruses could infected the amantadine hydrochloride-MDCK cells $(2 \mu \mathrm{g} / \mathrm{ml}$ and $4 \mu \mathrm{g} / \mathrm{ml}$ concentrations). However, clade 2.3.2 H5N1 subtype from Indonesia isolated at 2013 (EID $_{50} 10^{6}$ $10^{7}$ ) in MDCK cells could be inhibited by the antiviral drug of amantadine hydrocloride $(2 \mu \mathrm{g} / \mathrm{ml}$ and $4 \mu \mathrm{g} / \mathrm{ml}$ concentrations). The results revealed that these viruses were unsusceptible to amantadine. The correlation of in vitro assay, HA and molecular analysis results of H5N1 subtype of clade 2.3.2 from Indonesia isolated at 2013 and 2016 are presented in Table 1. 
Table 1. The correlation of in vitro assay, HA and genetic analysis results of clade 2.3.2 subtype H5N1 from waterfowl in Indonesia isolated at 2013 and 2016

\begin{tabular}{|c|c|c|c|c|c|}
\hline Avian influenza of clade 2.3 .2 & $\mathrm{EID}_{50}$ & $\begin{array}{l}\text { Protein } \\
\text { M2 }\end{array}$ & $\mathrm{CPE}$ & HA titer & $\begin{array}{c}\text { Susceptibility } \\
\text { of amantadine with } 2 \mu \mathrm{g} / \mathrm{ml} \text { and } 4 \mu \mathrm{g} / \mathrm{ml} \\
\text { amantadine hydrochloride concentrations }\end{array}$ \\
\hline A/duck/Indonesia/Brs 17/2013(H5N1) & $10^{6}$ & V27I & No CPE & negative & sensitive \\
\hline A/duck/Indonesia/Brs 17/2013(H5N1) & $10^{7}$ & V27I & No CPE & negative & sensitive \\
\hline A/duck/Indonesia/Brs 17/2013(H5N1) & $10^{8}$ & V27I & CPE & positive & resistant $(2 \mu \mathrm{g} / \mathrm{ml}$ and $4 \mu \mathrm{g} / \mathrm{ml})$ \\
\hline A/duck/Indonesia/Brs 34/2013(H5N1) & $10^{6}$ & V27I & CPE not clear & negative & sensitive \\
\hline A/duck/Indonesia/Brs 34/2013(H5N1) & $10^{8}$ & V27I & CPE & positive & resistant $(2 \mu \mathrm{g} / \mathrm{ml}$ and $4 \mu \mathrm{g} / \mathrm{ml})$ \\
\hline A/duck/Indonesia/Brs 62/2013(H5N1) & $10^{6}$ & V27I & CPE & positive & resistant $(2 \mu \mathrm{g} / \mathrm{ml}$ and $4 \mu \mathrm{g} / \mathrm{ml})$ \\
\hline A/duck/Indonesia/Brs 62/2013(H5N1) & $10^{7}$ & V27I & $\mathrm{CPE}$ & positive & resistant $(2 \mu \mathrm{g} / \mathrm{ml}$ and $4 \mu \mathrm{g} / \mathrm{ml})$ \\
\hline A/duck/Indonesia/Brs 62/2013(H5N1) & $10^{8}$ & V27I & CPE & positive & resistant $(2 \mu \mathrm{g} / \mathrm{ml}$ and $4 \mu \mathrm{g} / \mathrm{ml})$ \\
\hline A/m.duck/Indonesia/Serang/Srg 17/2016/H5N1 & $10^{6}$ & V27I & $\mathrm{CPE}$ & positive & resistant $(2 \mu \mathrm{g} / \mathrm{ml})$ \\
\hline A/m.duck/Indonesia/Serang/Srg 17/2016(H5N1 & $10^{7}$ & V27I & CPE & positive & resistant $(2 \mu \mathrm{g} / \mathrm{ml})$ \\
\hline A/duck/Indonesia/Lamongan/Lmn Tr/2016(H5N1 & $10^{6}$ & V27I & $\mathrm{CPE}$ & positive & resistant $(2 \mu \mathrm{g} / \mathrm{ml}$ and $4 \mu \mathrm{g} / \mathrm{ml})$ \\
\hline A/duck/Indonesia/Lamongan/Lmn Tr/2016(H5N1 & $10^{7}$ & V27I & CPE & positive & resistant $(2 \mu \mathrm{g} / \mathrm{ml}$ and $4 \mu \mathrm{g} / \mathrm{ml})$ \\
\hline A/duck/Indonesia/Lamongan/Lmn Tr/2016(H5N1 & $10^{8}$ & V27I & CPE & positive & resistant $(2 \mu \mathrm{g} / \mathrm{ml}$ and $4 \mu \mathrm{g} / \mathrm{ml})$ \\
\hline
\end{tabular}




\section{Discussion}

Domestic duck and other wild waterfowl are known as natural reservoir for avian influenza viruses. These waterfowls can take different subtypes of hemagglutinin and neuraminidase subtypes of avian influenza viruses with the silent nature of infections, no sign or mild diseases. Recently, the clade 2.3.2 of avian influenza viruses has been circulated in Southeast Asia including Indonesia and Vietnam (Dharmayanti et al. 2014). The viruses cause severe disease with neurological symptoms, fatality to domestic ducks and predominantly replicates in the brain, heart and lung organs. The excretion of virus through the upper respiratory and conjunctiva can spread virus to environment, poses the high risk of virus spread through cross-contact (Bui et al. 2014). The H5N1 subtype of clade 2.3.2 viruses from Indonesia used in this study were isolated from harvested tissues and tracheal swabs samples of dead or no clinical symptoms ducks through replicated in specific pathogen free (SPF) eggs.

Previous studies had already indicated that avian influenza viruses of $\mathrm{H} 5 \mathrm{~N} 1$ subtype in this research were clade 2.3.2 viruses based on HA gene. Analysis of the M2 gene phylogenetic tree presented that all avian influenza viruses of H5N1 subtype used in this study were closely correspond to avian influenza viruses of H5N1 subtype in Vietnam, China and Hong Kong (Wan et al. 2011; Naguib et al. 2015; Le \& Nguyen 2014; Bi et al. 2015). Futhermore, all of clade 2.3.2 from Indonesia isolated at 2013 and 2016 were closer to cluster of clade 2.3.2 from Vietnam.

Prior to this report, another study (Dharmayanti et al. 2014) had already characterized the M2 Val27Ile mutation of $\mathrm{H} 5 \mathrm{~N} 1$ subtype viruses of 2.3.2 clade caused duck outbreak in Indonesia at 2012. These studies suggest that the M2 Val27Ile substitution is similar between clade 2.3.2 H5N1 subtype from Indonesia isolated at 2012, 2013 and 2016. The pattern of M2 residues in clade 2.1 subtype $\mathrm{H} 5 \mathrm{~N} 1$ viruses were different since the majority of viruses circulating in Southeast Asia, especially Indonesia, had single or double substitution on amantadine resistance marker (Val27Ala and Ser31Asn). Amino acid mutation of the M2 protein avian influenza viruses at positions Leu26, Val27, Ala30, Ser31, Gly34, His37 and Trp41 can lead the adamantanes resistance including amantadine and rimantadine. The adamantanes resistance was found in the most influenza A viruses. One or more of M2 amino acids substitution involved amantadine resistance (Cheung et al. 2006; Dharmayanti et al. 2014).

The M2 Val27Ile mutation of six H5N1 subtype avian influenza viruses used in this study was unusually genetic markers of resistant viruses. Analysis of the M2 amino acid confirmed with in vitro test showed that H5N1 subtype of clade 2.3.2 from Indonesia isolated at
2013 and 2016 which had M2 Val27Ile substitution were resistant to amantadine because these viruses induced cytopathic effects in MDCK cells containing the highest non-toxic amantadine concentration.

The M2 Val27Ile, Ser31Asn, Leu26Phe mutations were also found in the other subtype, H4N2, H4N6 and H4N8 subtypes circulated in poultry in China. The single substitution of M2 Val27Ile was characterized in subtype $\mathrm{H} 4 \mathrm{~N} 2$ and the M2 S31N mutation was identified in subtype H4N6. In addition to single substitution, double substitutions of M2 Val27Ile and Leu26F were also found in subtype H4N8. These mutations are amantadine resistance marker (Liang et al. 2016). The M2 Val27Ile substitution was also identified and characterized in avian influenza viruses received from human clinic samples in Singapore (Lee et al. 2015). This describes that the M2 Val27Ile substitution of human and bird H5N1 subtype of avian influenza viruses may induce amantadine resistance.

The amantadine resistance of subtype $\mathrm{H} 5 \mathrm{~N} 1$ and seasonal flu viruses has been increasing recently (Zhou et al. 2011). The subtype H5N1 isolated from birds in Northern China has been sustained amantadine resistance up to $83.3 \%$. Amantadine antiviral drugs are intensively used for treatment of $\mathrm{H} 5 \mathrm{~N} 1$ subtype of avian influenza infections in poultry farms of China. The treatment with amantadine continuously has been intended to prophylaxis so that this condition plays a role important to produce amantadine resistance (He et al. 2008).

The phenotypic analysis (in vitro assay) was performed to confirm whether this substitution (V27I) in the M2 gene caused the amantadine resistance. Rapid test of amantadine resistant avian influenza viruses can be demonstrated in the HA assay after viruses replicated in MDCK cell with amantadine drug. The HA test is relatively simple compared to other tests. The avian influenza viruses of subtype H5N1 viruses was resistant to amantadine when HA test showed positive HA reaction $\left(>2^{2}\right)$ and the non-toxic concentration of amantadine hydrocloride $(\geq 0.19 \mu \mathrm{g} /$ $\mathrm{ml}$ ) (Jacob et al. 2016). The result of HA tests were related with the morphology of MDCK cell and the marker molecular of amantadine resistance of five H5N1 avian influenza viruses clade 2.3.2 from Indonesian. Result in Table 1 showed the amantadine resistant viruses induced the formation of $\mathrm{CPE}$ in MDCK cells and the positive HA reaction $\left(>2^{2}\right)$ with non-toxic concentration in MDCK cells $(2 \mu \mathrm{g} / \mathrm{ml}$ and 4 $\mu \mathrm{g} / \mathrm{ml})$.

The result of this research indicated that resistant viruses may still replicate in MDCK cells containing the highest amantadine concentration. The results of genetic analysis, in vitro assay and HA represented that clade 2.3.2 subtype H5N1 from Indonesia isolated at 2013 and 2016 were resistant for amantadine drugs. 
Treatment or prophylaxis of avian influenza infection in Indonesian poultry farms with amantadine have not been officially reported so far. The utilization of amantadine to prophylaxis in chickens is one of factors that to play a role for amantadine resistance. The other factor likely to contribute for amantadine resistance is wild birds migration. Migration of wild birds infected with amantadine resistance avian influenza is potential to transmit the amantadine resistance AIV among birds in Indonesia. Previous study (Dharmayanti et al. 2014) revealed that H5N1 subtype of 2.3.2 which has the M2 Val27Ile mutation circulated in Indonesia is probably introduction from overseas viruses.

\section{CONCLUSION}

The amantadine resistant avian influenza of clade 2.3.2 H5N1 subtype from Indonesia produced the formation of $\mathrm{CPE}$ and the positive $\mathrm{HA}$ reaction with non-toxic concentration of amantadine hydrochloride in MDCK cells. The substitution (V27I) was characterized in clade 2.3.2 H5N1 subtype from Indonesia. The result of genetic analysis of M2 gene for amantadine resistance was associated with the results of HA test and the formation of CPE in MDCK cells. These results indicated that amantadine resistance has been identified in avian influenza of clade 2.3.2 subtype $\mathrm{H} 5 \mathrm{~N} 1$ viruses from Indonesia.

\section{ACKNOWLEDGMENT}

This work were supported by APBN from Ministry of Agriculture, Republic of Indonesia.

\section{REFERENCES}

Bi Y, Zhang Z, Liu W, Yin Y, Hong J, Li X, Wang H, Wong G, Chen J, Li Y, et al. 2015. Highly pathogenic Avian Influenza $\mathrm{A}(\mathrm{H} 5 \mathrm{~N} 1)$ virus struck migratory birds in China in 2015. Sci Rep. 5:12986.

Bui VN, Dao TD, Nguyen TTH, Nguyen LT, Bui AN, Trinh DQ, Pham NT, Inui K, Runstadler J, Ogawa $\mathrm{H}$, et al. 2014. Pathogenicity of an H5N1 avian influenza virus isolated in Vietnam in 2012 and reliability of conjunctival samples for diagnosis of infection. Virus Res. 179:125-132.

Cheung C, Rayner JM, Smith GJ, Wang P, Naipospos T, Zhang J, Yuen K, Webster RG, Peiris Jsm, Guan Y, Chen H. 2006. Distribution of amantadine-resistant H5N1 Avian Influenza variants in Asia. J Infect Dis. 193:1626-1629. DOI: 10.1086/504723.

Dharmayanti N, Ibrahim F, Soebandrio A. 2010. Amantadine Resistant of Indonesian H5N1 Subtype Influenza
Viruses During 2003-2008. Microbiol Indones. 4:1116.

Dharmayanti NLPI, Hartawan R, Hewajuli DA, Hardiman, Wibawa H, Pudjiatmoko. 2013. Molecular characteristic and pathogenicity of Indonesian $\mathrm{H} 5 \mathrm{~N} 1$ clade 2.3.2 viruses. JITV. 18:99-113.

Dharmayanti N, Hartawan R, Pudjiatmoko H, Wibawa, Hardiman A, Balish R, Donis CT, Davis, Samaan G. 2014. Genetic Characterization of Clade 2.3.2.1 Avian Influenza A(H5N1) Viruses, Indonesia, 2012. Emerg Infect Dis. 20:677-680.

Dharmayanti NLPI, Hartawan R, Hewajuli DA. 2016. Development of primers for Reverse Transcriptase Polymerase Chain Reaction to detect avian influenza virus in Indonesia. J Vet.17 (2) : 183 - 196.

East M, Nations U, Organisation W, Health A. 2018. Antigenic and genetic characteristics of zoonotic influenza viruses and development of candidate vaccine viruses for pandemic preparedness. Relev Epidemiol Hebd. 93(12):142-152.

He G, Qiao J, Dong C, He C, Zhao L, Tian Y. 2008. Amantadine-resistance among $\mathrm{H} 5 \mathrm{~N} 1$ avian influenza viruses isolated in Northern China. Antiviral Res. 77(1):72-76.

Hoffmann E, Stech J, Guan Y, Webster RG, Perez DR. 2001. Universal primer set for the full-length amplification of all influenza A viruses. Arch Virol. 146:2275-2289. DOI: $10.1007 / \mathrm{s} 007050170002$.

Ison MG. 2013. Clinical use of approved influenza antivirals: therapy and prophylaxis. Influenza Other Respi Viruses. 7:7-13. DOI: 10.1111/irv.12046.

Jacob A, Sood R, Chanu KV, Bhatia S, Khandia R, Pateriya AK, Nagarajan S, Dimri U, Kulkarni DD. 2016. Amantadine resistance among highly pathogenic avian influenza viruses (H5N1) isolated from India. Microb Pathog. 91: 35 - 40.

Le TH, Nguyen NTB. 2014. Evolutionary dynamics of highly pathogenic avian influenza A/H5N1 HA clades and vaccine implementation in Vietnam. Clin Exp Vaccine Res. 3:117. DOI: 10.7774/cevr.2014.3.2.117.

Lee MS, Chang PC, Shien JH, Cheng MC, Shieh HK. 2001. Identification and subtyping of avian influenza viruses by reverse transcription-PCR. J Virol Methods. 97 (1-2) : 13 - 22.

Lee HK, Tang JW-T, Loh TP, Hurt AC, Oon LL-E, Koay ESC. 2015. Molecular surveillance of antiviral drug resistance of Influenza A/H3N2 virus in Singapore, 2009-2013.Schmolke M, editor. PLoS One. 10:e0117822. DOI: 10.1371/journal.pone.0117822.

Liang L, Deng G, Shi J, Wang S, Zhang Q, Kong H, Gu C, Guan Y, Suzuki Y, Li Y, et al. 2016. Genetics, receptor binding, replication, and mammalian transmission of $\mathrm{H} 4$ Avian Influenza viruses isolated from live poultry markets in China.Dermody TS, editor. J Virol. 90:1455-1469. DOI: 10.1128/JVI.02692-15. 
Naguib MM, Kinne J, Chen H, Chan K-H, Joseph S, Wong PC, Woo PCY, Wernery R, Beer M, Wernery U, Harder TC. 2015. Outbreaks of highly pathogenic avian influenza $\mathrm{H} 5 \mathrm{~N} 1$ clade 2.3.2.1c in hunting falcons and kept wild birds in Dubai implicate intercontinental virus spread. J Gen Virol. 96:3212-3222. DOI: 10.1099/jgv.0.000274.

OIE Terrestial Manual. 2021. Avian influenza (including infection with high pathogenicity avian influenza viruses. Chapter 3.3.4

Reed LJ, Muench H. 1938. A simple method of estimating fifty per cent endpoints. Am J Epidemiol. 27:493-497. DOI: 10.1093/oxfordjournals.aje.a118408.

Smith GJD, Donis RO. 2015. Nomenclature updates resulting from the evolution of avian influenza $\mathrm{A}(\mathrm{H} 5)$ virus clades 2.1.3.2a, 2.2.1, and 2.3.4 during 2013-2014. Influenza Other Respi Viruses. 9(5):271-276.

Swayne D. 2021. Avian influenza (including infection with high pathogenicity avian influenza viruses. In: OIE Terrestial Man. Paris (Fr): OIE.

Wan X-F, Dong L, Lan Y, Long L-P, Xu C, Zou S, Li Z, Wen L, Cai Z, Wang W, et al. 2011. Indications that live poultry markets are a major source of Human H5N1
Influenza virus infection in China. J Virol. 85:1343213438. DOI: 10.1128/JVI.05266-11.

WHO-OIE-FAO H5N1EWG. 2014. Revised and updated nomenclature for highly pathogenic avian influenza A (H5N1) viruses. Influenza Other Respi Viruses. 8(3):384-388.

Wibawa H, Bingham J, Nuradji H, Lowther S, Payne J, Harper J, Junaidi A, Middleton D, Meers J. 2014. Experimentally infected domestic ducks show efficient transmission of Indonesian $\mathrm{H} 5 \mathrm{~N} 1$ highly pathogenic Avian Influenza virus, but lack persistent viral shedding.Davis T, editor. PLoS One. 9:e83417. DOI: 10.1371/journal.pone.0083417.

Wright KE, Wilson GA, Novosad D, Dimock C, Tan D, Weber JM. 1995. Typing and subtyping of influenza viruses in clinical samples by PCR. J Clin Microbiol. 33:1180-1184. DOI: $\quad 10.1128 / \mathrm{jcm} .33 .5 .1180$ 1184.1995.

Zhou J, Zou L, Zhang X, Liao J, Ni H, Hou N, Wang Y, Li H, $\mathrm{Wu} \mathrm{J}$, Jonges $\mathrm{M}$, et al. 2011. Adamantane- and oseltamivir-resistant seasonal A (H1N1) and pandemic A (H1N1) 2009 Influenza viruses in Guangdong, China, during 2008 and 2009. J Clin Microbiol. 49:2651-2655. DOI: 10.1128/JCM.00535-11. 